\title{
Medical Tourism: Analysis of the State of International Tourism and Prospects for Domestic Development
}

\author{
Igor Turski ${ }^{1, *}$, Hanna Mashika², Tetiana Tkachenko ${ }^{3}$, Maryna Khmara ${ }^{4}$, Igor Komarnitskyi ${ }^{5}$, \\ Mariia Oliinyk $^{6}$ \\ ${ }^{1}$ Department of Tourism, Hotel and Restaurant Business, Lutsk National Technical University, Lutsk, Ukraine \\ ${ }^{2}$ Department of Tourism, Uzhgorod National University, Uzhorod, Ukraine \\ ${ }^{3}$ Department of Tourism and Recreation, Kyiv National University of Trade and Economics, Kyiv, Ukraine \\ ${ }^{4}$ Department of International Business, Taras Shevchenko National University of Kyiv, Kyiv, Ukraine \\ ${ }^{5}$ Faculty of Hotel, Restaurant and Tourism Business, Kyiv National University of Culture and Arts, Kyiv, Ukraine \\ ${ }^{6}$ Department of International Accounting and Audit, Kyiv National Economic University, Kyiv, Ukraine
}

Received December 27, 2020; Revised February 7, 2021; Accepted March 12, 2021

\section{Cite This Paper in the following Citation Styles}

(a): [1] Igor Turski, Hanna Mashika, Tetiana Tkachenko, Maryna Khmara, Igor Komarnitskyi, Mariia Oliinyk, "Medical Tourism: Analysis of the State of International Tourism and Prospects for Domestic Development," Universal Journal of Public Health, Vol. 9, No. 2, pp. 27 - 34, 2021. DOI: 10.13189/ujph.2021.090201.

(b): Igor Turski, Hanna Mashika, Tetiana Tkachenko, Maryna Khmara, Igor Komarnitskyi, Mariia Oliinyk (2021). Medical Tourism: Analysis of the State of International Tourism and Prospects for Domestic Development. Universal Journal of Public Health, 9(2), 27 - 34. DOI: 10.13189/ujph.2021.090201.

Copyright@2021 by authors, all rights reserved. Authors agree that this article remains permanently open access under the terms of the Creative Commons Attribution License 4.0 International License

\begin{abstract}
Medical tourism is a relatively popular area of tourism, and the primary purpose is to organize the treatment of a patient abroad. It differs from usual tourism in that rest abroad is combined with medical services, which are ready to provide the world's leading centres and clinics. The study is devoted to developing recommendations for ensuring the sustainable development of Ukrainian medical tourism, based on the analysis of international tourism achievements. In their study, the authors similarly considered the very concept of medical tourism, its features and main directions, namely, the authors deemed such directions as diagnostic, therapeutic, rehabilitation, health-improving and non-traditional tourism. The authors examined the leading countries of inbound medical tourism, as well as the key incentives for such tourists. Analysis of the growth dynamics of medical tourists by year and the main directions of medical tourism in Ukraine allowed the authors to highlight the most promising Ukrainian medical tourism destinations. In conclusion, the authors analyzed the benefits of international and Ukrainian medical tourism. Summing up, the authors concluded that medical tourism in Ukraine is only at the initial stage of its development; however, certain regions have significant potential for its successful formation.
\end{abstract}

Keywords Bio Insurance, Healthy Lifestyle, Medical Assistance, Medical Tourism, Medical Tourism Index Score, Medical Services, Sports

\section{Introduction}

The country's development and prosperity, labour, intellectual and demographic potential directly depend on its citizens' health. Health is the leading and indisputable component of active life and everyday human existence, but the human body's functional capabilities are not unlimited. In the conditions of the rapidly growing pace of modern life, the acceleration of scientific and technological progress, which entail not only positive, but inevitably emerging negative consequences for health, there is a pronounced depletion of the defences of the human body and, as a consequence, deterioration of the activity of the most critical systems and life support organs. There is a significant increase in the incidence of the population and the "rejuvenation" of diseases traditionally characteristic of the elderly, such as strokes, cardiovascular and oncological diseases, diseases of the musculoskeletal system, the emergence of new, more 
dangerous diseases. Unfavourable environmental conditions, constant stress loads lead to physical and mental fatigue, ageing of the body; therefore, care for human health has become an integral part of the modern value system. There is a growing number of people striving to lead a healthy lifestyle, aimed at active, disease-free longevity, living according to the principle it is better to prevent a disease than to cure it, and, if necessary, receive timely and high-quality medical care.

Travels with health-improving and therapeutic purposes have been known since the 18th century, when a particular circle of well-to-do people travelled to "get water treatment" for gout, liver diseases, bronchitis and tuberculosis to famous balneological resorts - Karlsbad in the Czech Republic, Baden-Baden in Germany, Baden in Switzerland, Vichy in France, Nice in France, Monte Carlo in Monaco. In our time, globalization and the rapid development of information technologies have led to the emergence of such a concept in medicine as medical tourism. The liberalization of society has led to the fact that now the patient chooses a specialist who will receive treatment and the country where he will receive the necessary assistance. According to the World Health Association forecasts, medical tourism can turn into one of the most promising sectors of the world economy and affect the level of public health. The number of states competing for patients in the medical tourism market is steadily growing, and our country faces the urgent task of taking a worthy and lasting place on it.

\section{Theoretical Section}

Medical tourism is a direction of tourism, the purpose of which is to organize and receive a person, according to medical indications, qualified full-fledged treatment, recovery and rehabilitation outside the region of residence [1-3]. There are three groups in medical tourism: domestic, outbound and inbound (Fig. 1).

Domestic medical tourism is not a new phenomenon and implies medical services by residents of one country in neighbouring regions within their own country [4-6]. In these cases, they seek medical help with the desire to get to highly qualified specialists in the field of treatment of certain diseases, and as a rule, these are residents of cities with a small population, in which there are no large specialized centres.

Outbound and inbound medical tourism are providing planned medical services outside the patient's country of residence $[7 ; 8]$. It is typical for outreach to treat a patient abroad to meet their own medical needs. Inbound medical tourism is aimed at attracting foreign patients to provide them with medical care.

Modern medical tourism is classified according to receiving medical services into diagnostic, therapeutic, rehabilitation, wellness and non-traditional $[9 ; 10]$.

In diagnostic medical tourism, to identify and determine the nature of the disease, if desired, to confirm or deny a diagnosis already made, a person goes to another country to undergo a thorough examination of the body using high-precision equipment and consult with highly qualified specialists. In medical tourism, planned treatment is carried out with the necessary therapeutic technologies or surgical interventions to treat a disease already identified in a medical tourist. The rehabilitation direction of tourism aims to restore the lost functions of the body resulting from trauma, stroke, paralysis and other pathological processes.

Health tourism mainly affects various technologies for improving the health of a "healthy person" and improving their appearance (health improvement at resorts, dental care, plastic surgery, bariatrics, cosmetic procedures).

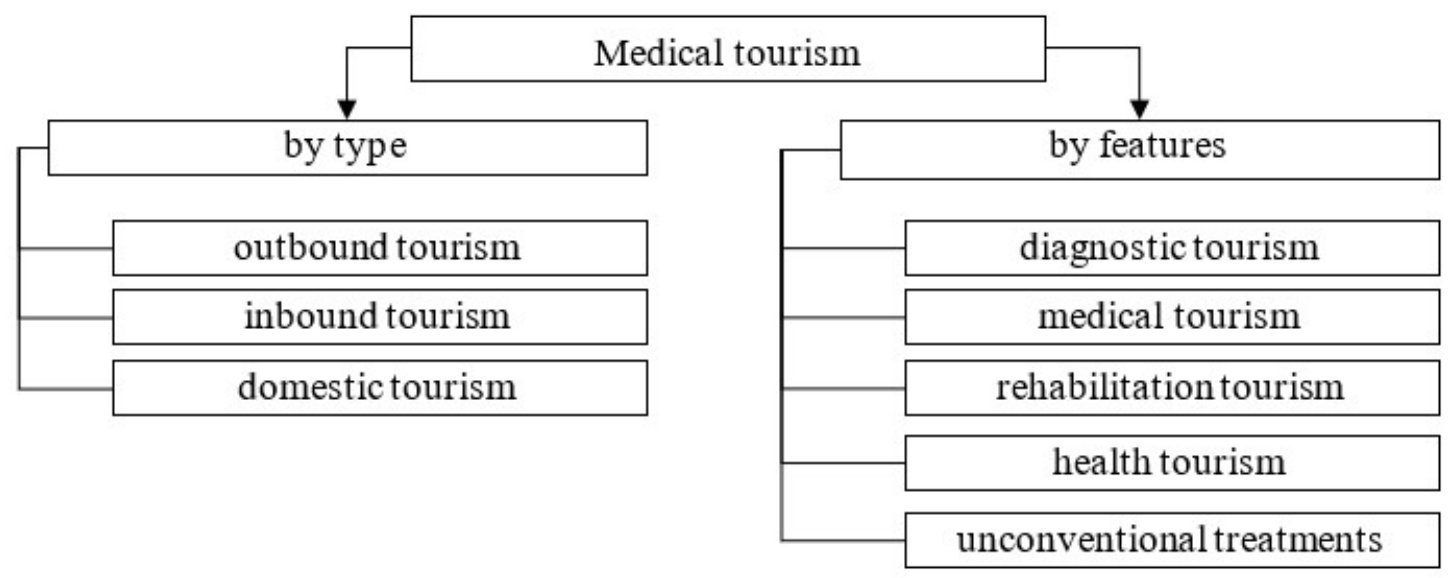

Figure 1. Classification of medical tourism 
We considered it necessary to highlight non-traditional methods based on methods that are significantly different from traditional ones. In many countries, some centres practice such areas as Buddhist teachings, yoga, Ayurvedic practice, Tibetan medicine and other techniques with extensive use of acupuncture, massage and herbal medicine. These methods of recovery and treatment without drugs find adherents in many countries around the world.

The socio-economic reasons for which people resort to medical tourism services are different. According to the Medical Tourism Association, the decisive factors in choosing a country of treatment are the cost of medical care (33\%) and the quality of medical care (42\%) (Fig. 2).

\section{Motivation of medical tourism}

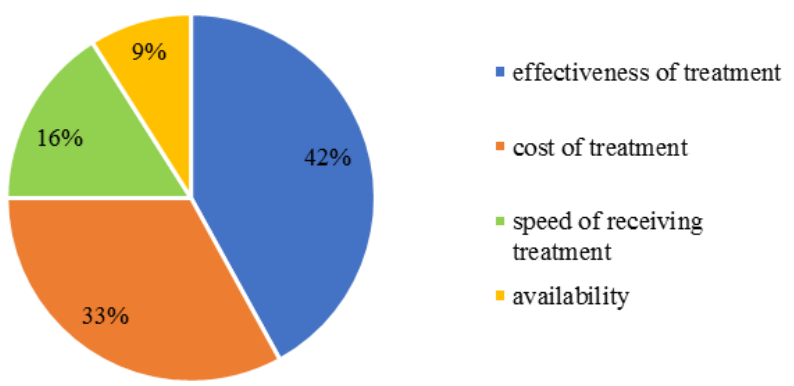

Figure 2. Key drivers of medical tourism

High prices sometimes make qualified medical care inaccessible to citizens of developed countries within their country. For example, in the United States, a recognized leader in medical tourism, the number of people whose insurance does not cover the treatment of chronic severe diseases is approaching 110 million, and part of the population, due to the economic crisis and falling living standards, generally prefer to refuse health insurance, and in case of illness receive less expensive but effective treatment in another country [11]. Savings on medical services in developing countries can reach from $30 \%$ to $85 \%$, so coronary artery bypass surgery in Turkey costs about 10 times less than in the United States, removal of cataracts in both eyes in America will cost a patient $\$ 4,000$, and in neighbouring Mexico in 1900.

Medical tourism is prevalent among residents of Canada, Great Britain, and Sweden. The state in these countries covers up to $90 \%$ of the cost of medical services. Still, to get, for example, a consultation with a necessary medical specialist, sometimes you have to wait several months. The waiting time for a planned operation is on average about two years, and such extended periods can lead to a significant worsening during the disease.

Due to regulatory, religious prohibitions and restrictions, many patients cannot receive certain medical services in their country - this is surrogacy, oocyte donation, gender reassignment, euthanasia, abortion, treatment with narcotic drugs.

There is also a significant flow of patients from poorer countries with a low level of medicine development to the leading countries of medical tourism when a trip abroad becomes the only hope for recovery [12; 13]. In this direction, oncology, cardiac surgery, orthopaedics and neurosurgery are in demand in Germany, Israel, Switzerland, Austria, and France.

Currently, more than 70 countries consider the development of medical tourism a priority direction of state policy. Medical tourism is a dynamic system; in addition to the recognized leaders in this field, new competitive countries of Asia, Latin America, the Middle East, and more recently the countries of North Africa, in which the solution of the problems of developing medical tourism is set on a government level with significant investment in medical infrastructure to improve patient care. The top 10 destinations worldwide in the overall medical tourism index for 2020 are as follows (Fig. 3).

\section{Medical tourism index score}

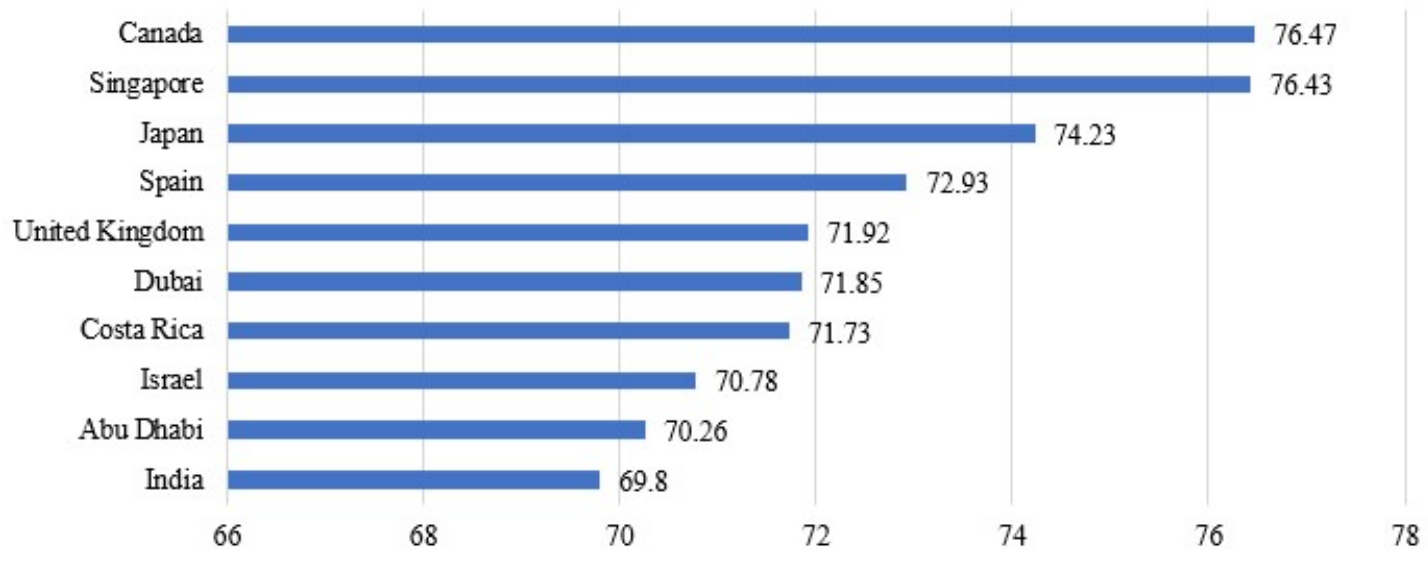

Figure 3. Top 10 international medical tourism destinations in 2020 [3; 12] 
The infrastructure of the global market for medical services is a complex and multifaceted system, which includes, in addition to medical institutions, health resorts, accreditation bodies, medical and tourist tourism agencies, hotel complexes, legal aid, insurance, advertising, financial institutions, transport, communications, media [13]. Medical tourism cannot exist without a developed infrastructure $[14 ; 15]$.

The World Health Organization has recognized differences in health standards in different countries; therefore, attempts have been made to standardize medical care provision, primarily concerning emergency medical care. Planned therapeutic and surgical care, rehabilitation and diagnostics methods, and methods of attracting potential patients in different countries have their specifics, which gives foreign tourists a broad scope for choice.

For example, the high professional level of Israeli medicine is known worldwide and does not need advertising, but Israeli clinics continue to make and improve their efforts to attract foreign patients. The most Israeli public and private clinics have an international department, whose employees organize consultations with specialized specialists, draw up a preliminary plan of diagnostic and treatment procedures, calculate the cost of treatment and, if the patient responds positively, organize the arrival and placement, accompany patients in the process stay in the country. There is also a widely developed service of medical providers that are not tied to a specific clinic, who organize consultations with specialists from different clinics and provide services for changing a doctor or clinic at the patient's request. International departments at clinics and intermediary companies in medical tourism are so crucial for the success of medical institutions that they have developed and exist in different countries of the world.

In Germany, another leader in the medical services market has established close cooperation between research centres and clinics, where the latest advances in diagnostics and treatment are instantly introduced into practice, close cooperation between clinics is developed, therefore, at the request of the patient or in case of difficulties in diagnosis and treatment, you can get expert advice from a doctor from another medical institution. In addition to treatment, in Germany, the program of a comprehensive examination of the body "Basic Check-up" is popular, which allows you to examine the state of health in a day fully, often people accompanying the patient use this procedure. Austria, making extensive use of its unique natural features, has risen to the top of the world rankings in the development of health and rehabilitation medical tourism. In contrast, the tourism sector, which is closely related to health tourism, has also been widely developed. South Korea and China build their work based on the most advanced technologies in close cooperation with scientific institutions. Still, they also widely draw on the wealthy, centuries-old, practical experience of oriental medicine.

The visa policy of the state is significant for the development and support of medical tourism. In most of the leading countries in medical tourism, a special medical visa is valid, facilitating and accelerating within no more than five days. In cases requiring urgent medical intervention, in one day, obtaining a visa and a medical visa, if necessary, it is possible to extend the period of stay in the country. In Turkey, medical tourists, upon completion of treatment, are refunded 50\% of the airfare. Patients travel to receive high-quality high-tech medical care and seek to minimize risks; therefore, when looking for a clinic, they first pay attention to the presence of a certificate of compliance with international standards Joint Commission International, QHR trend, etc. According to JCI 20 private and public clinics are accredited in Israel, and more than 40 in Turkey.

In our country, medical tourism not so long ago began to take shape in a special direction, and to take its place in the market of medical services; it is necessary to take several serious steps in the field of healthcare and the creation of appropriate infrastructure. At the same time, it is useful to study foreign countries' experience and find our national differences inherent only in our country, which will allow us to compete in the world arena of medical tourism. Every year in Ukraine, inbound and health-improving medical tourism becomes more and more popular. In 2018, about 60 thousand foreigners came to Ukraine for treatment. In 2019, about 65 thousand medical patients from abroad visited the country, which, according to rough estimates, brought our state about $\$ 182$ million and the growth in this industry is predicted by $10-20 \%$ in a year. The Ukrainian Association of Medical Tourism published such data, and according to forecasts, about 100 thousand medical tourists should have visited our country in 2020, but the coronavirus pandemic has made its own adjustments (Fig. 4). 


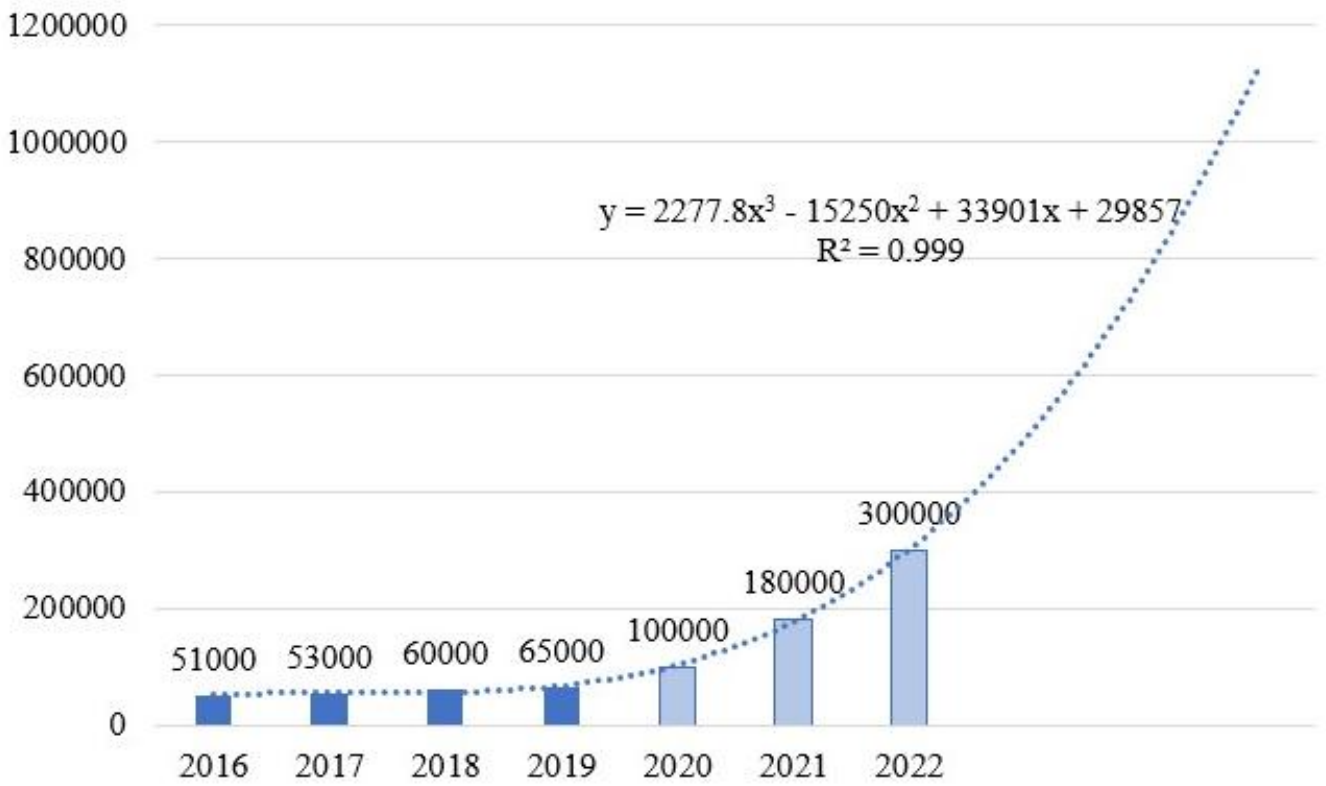

Figure 4. Dynamics of growth of medical tourists by years

The geography of inbound medical tourism is also changing, if earlier it was mainly tourists from the former CIS countries or representatives of the Ukrainian diaspora abroad, now they make up $45 \%$ of the total number of medical tourists who visited our country, and $55 \%$ of tourists come from Europe, Israel, Spain, Italy, Bahrain, Saudi Arabia, Iraq, UAE [11]. This is an indicator of the growing image of our country in the international arena. More and more foreigners consider Ukraine a provider of medical services with an excellent price-quality ratio because Ukrainian doctors have established themselves as highly qualified specialists. The level of our private medicine is not inferior to the world level. The lack of queues to highly specialized doctors and the opportunity to receive quality treatment from the first days of contacting a specialist also affect. Treatment in Ukraine is $30-70 \%$ cheaper than world prices, while the quality of the services provided remains high.

Ukraine has a lot to be proud of in the provision of medical services. Here are some examples of selected, well-known far beyond the country's borders, providers of medical services that are in demand among foreign medical tourists. Odessa centre of post-burn eye pathology has no analogues in the world. Throughout his work, he received thousands of foreign patients and helped restore sight to people from more than 50 countries. The Swedish-Ukrainian medical centre Angelholm in Chernivtsi specializing in joint replacement, back and injury treatment, is widely known and accepts patients from Ukraine and all over the world. There are 34 specialized reproductive health clinics in Ukraine that treat all forms of infertility by the standards of the World Health Organization (WHO) and the European Association for Human Reproduction and Embryology, which made it possible to learn the joy of motherhood to thousands of women from different countries of the world, and the number of those wishing to get with these problems it is in Ukraine that is constantly growing. The created dental portal of Ukraine, on the site of which more than 1000 dental clinics from all over Ukraine are collected, allows access to a selection of dental clinics, which is incredibly convenient for patients living abroad, as it helps them to contact the clinic, draw up a treatment protocol and keep in touch in the future with the clinic and the patient. At the moment, dental care remains the most in-demand due to the ratio - low cost with high quality of treatment, as well as the widespread practise among Ukrainian doctors of tooth preservation, even in advanced cases. It was created based on the National Institute of Cardiovascular Surgery. N.M. Amosova "Clinic of New Technologies", Center for Cardiac Surgery in Kyiv, built based on the Medical Center "Dobrobut", in which assistance is provided by highly qualified cardiologists and cardiac surgeons using innovative technologies, and diagnostic research and surgical operations are provided with the most modern equipment from leading world manufacturers. Ukrainian doctors take on even the most hopeless cases and in 90\% of these operations are successful, even though the cost of treatment is much lower than in foreign clinics. Ilaya medical company conducts and implements its developments in the field of cellular technologies. Its result was the introduction of such a unique service as bio insurance. This is an innovative method for storing mesenchymal stromal cells, which helps to quickly regenerate tissues after diseases, injuries, burns, as well as prevent tissue ageing. Ukraine is famous for its medical and health resorts due to its unique natural data, thermal springs, mud. These include Transcarpathia, Truskavets, Mirgorod, Khmelnik, Morshyn; the resorts of Odesa, Mykolaiv, Zaporizhzhia 
and Kyiv regions are also in demand. The rehabilitation clinic of Dr Kozyavkin, where doctors help patients with cerebral palsy and autism using a unique method, has been accepting patients for more than 20 years, including from abroad, is so well-known and in demand. The queue is scheduled for a year in advance that it became necessary to open branches in the UAE and Cyprus. The main directions of medical tourism in Ukraine are presented in Fig. 5.

\section{Evaluation of Results}

Currently, the global market for medical services has already formed. Still, an analysis of statistics on its development shows that this is a dynamic system in which there is a relatively rapid change in focus from one country to another.

Fierce competition in the medical services market forces the participating countries of medical tourism to develop medicine rapidly due to modern technologies and an increase in investment in this industry. Without support and assistance from the state, serious investments from both the state and private investors in the development of medical science, specialized education, technical base, medical infrastructure, and medical tourism development is impossible. We must not forget about the economic component of medical tourism - the formation of a competitive price in the context of the price-quality ratio. For most patients, the main factor in favour of travelling abroad is the cost of treatment [3]. The pricing policy that is currently observed in Ukraine is actively attracting medical tourists to our country; it is desirable to keep this trend.

It is necessary to improve the visa policy, in which serious steps have already been taken, for example, for citizens of 52 countries, the possibility of electronic registration of entry documents is open. In the first half of 2019 alone, more than 20 thousand foreigners used the service, and Ukraine earned 45 million hryvnias. At a meeting in Truskavets, President Volodymyr Zelenskyy proposed to cancel the visa regime for countries whose citizens most often come to us for treatment and recovery. For Ukraine to enter the international level and attract foreign patients, there is an acute issue of obtaining a certificate of compliance with international standards Joint Commission International (JCI), QHR trend, etc. In 39 countries of the world today, JCI has accredited more than 300 public and private healthcare organizations, which dramatically increases their prestige. It acts as a guarantor of the highest quality of medical care, patient safety, and the use of correct treatment methods. The first steps in this direction have already been taken, international certificates have been received by the National Heart Institute (in 2015) and the Isida private clinic (in the fall of 2018), in 2019 the Doctor Sam network of clinics and at the beginning of 2020 the Leleka maternity hospital received a certificate JCI. International certificates make it possible to actively cooperate with global insurance companies that pay for patients abroad and, if they have a certificate, are ready to collaborate with domestic clinics.

There is an acute issue of the development of information and communication means of medical tourism: this is the creation of an Internet platform with a list of all private and public medical institutions capable of providing medical services for foreign citizens; advertising in foreign media; promotion of exhibition activities, participation in congresses and conferences abroad. It is essential to develop close cooperation with medical service providers who organize the selection of clinics and specialists, prepare and translate medical and financial documents, resolve accommodation and relocation issues, and arrange transfers. It is necessary to increase the overall festive background of the country's perception on the world stage since travel safety is a critical component when choosing a country.

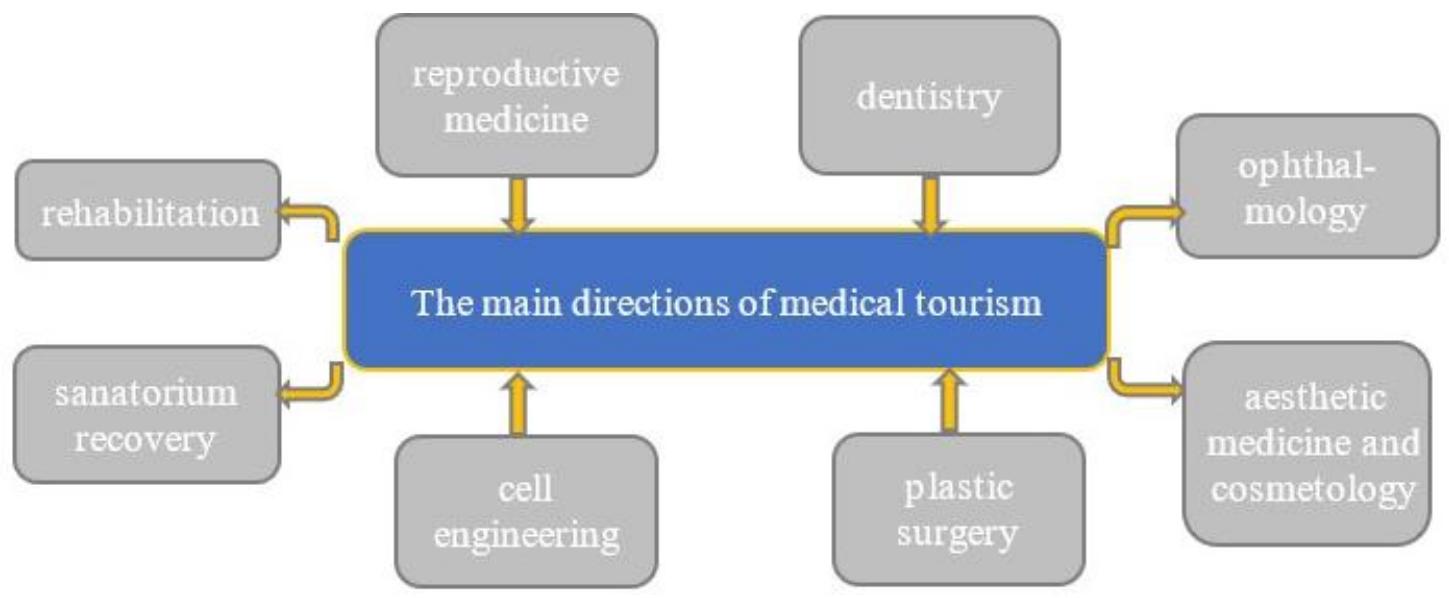

Figure 5. The main directions of medical tourism in Ukraine 
For successful communication with clients, it is necessary to minimize the language barrier between the patient and his attending physician and the service personnel, creating conditions for motivating the personnel to learn foreign languages.

It is vital to work with medical staff, for whom the norm of behaviour should be a respectful, friendly attitude towards the patient and a high culture of communication and comfort in the ward, which contributes to the creation of conditions for psychological and physical comfort. Therefore, the need to introduce a high world standard of service into medical practice remains relevant.

A new paradigm for the development of modern society, which appeared in connection with the increase in life expectancy, aimed at "active, disease-free longevity" will give an impetus to the further development of health-improving medical tourism.

Health tourism in Ukraine could compete with foreign ones since there are many thermal springs, mud, ozokerite deposits and similar unique natural resources in our country. For example, Ukraine ranks first in the world in terms of reserves of ozokerite. At the Boryslavskoye field in the Lviv region, up to $85 \%$ of the world's reserves of this mineral are concentrated, and in terms of quality, it has no equal, as only here pure ozokerite is found in the veins. However, this unique deposit is not being developed; the mine is abandoned.

$13 \mathrm{~km}$ from Odesa there is a unique natural object sanatorium "Kuyalnik" with sources of healing mineralized brine, silt mud and mineral water, one of the oldest balneo-mud resorts in Ukraine, specializing in the treatment of diseases of the nervous system, musculoskeletal system, skin diseases and infertility with mud, which in its composition is valued even more than the mud of the Dead Sea. The partial reconstruction of residential buildings and the updated medical base attracts patients from all over Ukraine; however, the resort's insufficiently developed infrastructure does not fully use the sanatorium's natural resources to attract foreign tourists. Resorts of Transcarpathia, Odesa, Mykolaiv, Zaporizhzhia and Kyiv regions, Truskavets, Mirgorod, Khmelnik, Morshyn have great potential for development, but the problem is the lack of state funding.

Summarizing all of the above, namely the international experience and the current state of the Ukrainian medical business, we propose a mechanism for forming a strategy for the sustainable development of medical tourism (Fig. $6)$.

From the analysis of the development of medical tourism in Ukraine, it can be concluded that the potential of Ukraine in the provision of high-quality medical services is significant. There are all the prerequisites for becoming its active participant. Still, it is necessary to promote internationally, improve service, develop infrastructure, introduce innovative technologies, buy modern equipment, and cooperate more closely with online platforms.

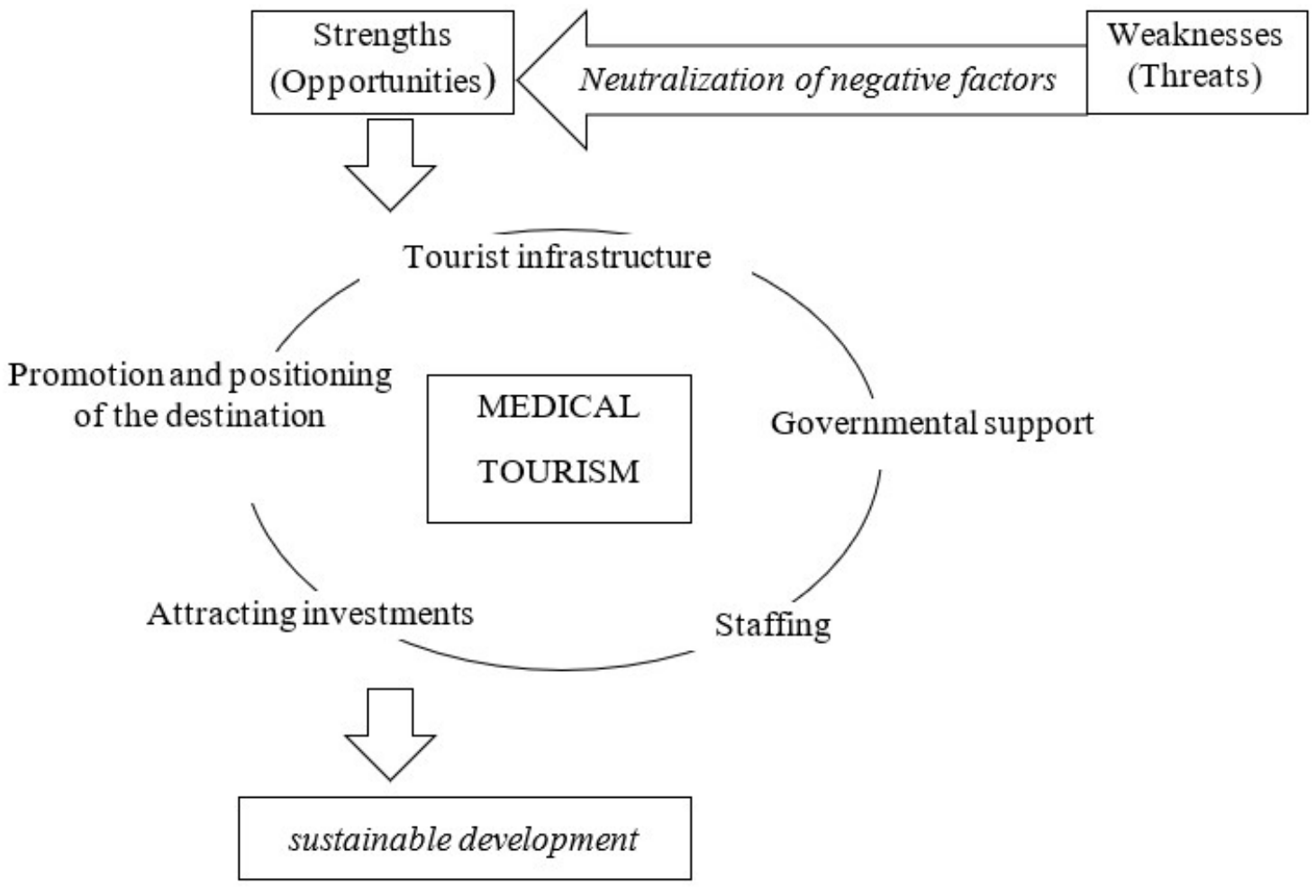

Figure 6. The mechanism for forming a strategy for the sustainable development of medical tourism 


\section{Conclusions}

Summing up the research, it is necessary to highlight several features. Thus, medical tourism in Ukraine is only at the initial stage of its development, however,

Benefits of international medical tourism:

- Modern diagnostic and therapeutic techniques that allow you to accurately establish a diagnosis and develop treatment in all areas of medicine;

- Innovative therapy based on painlessness and non-trauma;

- Maximum provision of equipment for institutions. The presence of all the necessary devices allows for the prompt treatment and rehabilitation of the patient;

- Unique medical services and procedures. Most of the services provided in clinics abroad are not available in their home country;

- Professionalism and high-quality service. The medical staff has all the necessary knowledge to support and assist patients undergoing treatment abroad effectively.

The benefits of medical tourism to Ukraine:

- Price-quality ratio. In comparison with European centres, medical services in Ukraine are cheaper with proper quality;

- Availability of rehabilitation centres and sanatoriums, where the rehabilitation of people and children with cerebral palsy is carried out;

- Developed dentistry and ophthalmology. In same Moldova, Belarus, Germany, the quality of dental services is lower, and prices are too high;

- Innovative cell technologies and advanced reproductive medicine. Stem cell transplant operations are prohibited in some countries, and in Ukraine, they have been successfully carried out for the past ten years;

- Developed surrogacy, which allows you to choose a surrogate mother and precisely program the sex of the unborn child.

This is what makes medical tourism in Ukrainian clinics more popular among residents of near and far abroad.

Thus, medical tourism in Ukraine is only at the initial stage of its development; however, certain regions have significant potential for its successful formation.

\section{REFERENCES}

[1] Lunt, N., Smith, R. D., Exworthy, M., Green, S. T., Horsfall, D. G., \& Mannion, R. Medical Tourism: Treatments, Markets and Health System Implications: A scoping review. OECD. http://www.oecd.org/els/health-systems/48723982. pdf, 2011.

[2] Bagga, T., Vishnoi, S. K., Jain, S., Sharma, R. Medical tourism: treatment, therapy \& tourism, International Journal of Scientific \& Technology Research, 9(3), pp. 4447-4453, 2020.

[3] Kaushik, D., Rustagi, A. Medical tourism: A global industry, Journal of Statistics and Management Systems, 23:7, pp. 1241-1249, DOI: 10.1080/09720510.2020.1799581, 2020.

[4] Lipianin-Zontek, E., Szewczyk, I. Adaptation of business hotels to the needs of disabled tourists in Poland, Problems and Perspectives in Management, Volume 17, Issue 4, pp. 392-403, 2019.

[5] Kim, J., Terry, D., Jang, S., Nguyen, H., Gilbert, J., Cruickshank, M. Public Perception of Medical Errors: Experiences and Risks Shared in Australia. Universal Journal of Public Health, 8(1), 35 - 41. DOI: 10.13189/ujph.2020.080104, 2020.

[6] Kim, S., Arcodia, Ch., Kim, I. Critical Success Factors of Medical Tourism: The Case of South Korea, International Journal of Environmental Research and Public Health, 16, 4964; DOI:10.3390/ijerph16244964, 2019.

[7] Mura, L., Ključnikov, A. Small businesses in rural tourism and agro tourism: Study from Slovakia. Economics and Sociology, 11(3), pp. 286-300, 2018.

[8] Muñoz-Leiva, F. Past themes and future trends in medical tourism research: A co-word analysis, Tourism Management, 65 (2018), pp. 200-211, 2017.

[9] Demikhov O., Dehtyarova I., Demikhova N. Actual aspects of public health policy formation on the example of Ukraine, Bangladesh Journal of Medical Science, vol. 19 (3), pp. 358-36. DOI: 10.3329/bjms.v19i3.45850, 2020.

[10] Aksoy, Y., Çankaya, S., Taşmektepligil, Y. M. (2017). The Effects of Recreational and Sports Activities on Psychological Status in Young People Aged 11-13 Years. Universal Journal of Public Health, 5(5), 217-221. DOI: 10.13189/ujph.2017.050503.

[11] Alleman, B., Luger, T., Reisinger, H., Martin, R., Horowitz, M., Cram, P. Medical Tourism Services Available to Residents of the United States, Journal of General Internal Medicine, 26(5), pp. 492-497 DOI: 10.1007/s11606-010-1582 $-8,2010$.

[12] Elflein, J. Top medical tourism countries by total index rating worldwide 2020.https://www.statista.com/statistics/8 89983/top-medical-tourism-countries-of-destination-by-tota 1-index-rating/

[13] Scott J.J., Fike D.S., Zhang S., Raehl C.L. Domestic Medical Tourism: Are Hospital Charges a Factor? The International Journal of Health, Wellness, and Society, 2 (1), pp. 63-74. DOI:10.18848/2156-8960/CGP/v02i01/41187, 2012.

[14] Fetscherin, M., Stephano, R-M. The medical tourism index: Scale development and validation, Tourism Management, Volume 52, pp. 539-556, DOI: 10.1016/j.tourman.2015.08. 010,2016

[15] Morito, Ch. Motives for Travel in Domestic Medical Tourism, Japan Marketing Journal, 39(4), pp. 42-52 DOI: 10.7222/marketing.2020.020, 2020. 